\title{
Culture \& Development: Lessons learnt from the Post-Election Violence in Kenya
}

\author{
Frederick Kang'ethe Iraki ${ }^{1}$
}

\begin{abstract}
Culture encompasses, without being reducible to, values and norms that underpin a people's way of thinking and doing things. Development on the other hand can be analyzed as any progression toward a goal. If this is the case then we instantly appreciate the nexus between the two concepts. A community will have a certain perception of the world (culture) and how it would like to transform that world to its own good (development) through various initiatives and processes.

Some scholars argue that development should be anchored in a people's culture. It cannot be brought to them from the outside because that would be someone else' idea of development (Boukary 2003). Others might argue that development can be introduced from outside to create awareness, then the culture of the people accommodates and domesticates it. In market studies terms, development should be a felt need by a community to develop a product in the case of the first theory or a product introduced into the market that people learn to appreciate in the latter scenario. We believe the two models are complementary.

This paper discusses the concepts of culture and development with respect to the post-election violence in Kenya that left 1,200 people dead and another 400,000 displaced from their homes. We recast the violence within the wider context of the history, cultural diversity and economics of Kenya. How can an island of peace for 45 years plunge into senseless killings overnight that negate a sound development record of $7 \%$ GDP growth?
\end{abstract}

Key words: culture, development, violence, ethnicity, values

\section{Introduction}

The term culture encapsulates, without necessarily being reduced to, what a community values or cherishes at a particular time. It is also accompanied by standards or norms that regulate the adherence to those values or desirables. To a large extent, there is some consensus in the community about the values and the norms.

Language - whether a creation or a product of a sudden instinct (Pinker 1994) - is one of the most powerful tools of promoting a culture. Further, it serves as a glue to bind its speakers. The

\footnotetext{
${ }^{1}$ My gratitude to Ms Adelaide Lusega, my graduate research assistant, for her diligence in collecting the material for this paper. All errors are mine.
} 
relationship between the two concepts, culture and language, is almost like the two sides of the same sheet of paper. Cultural transformations, e.g. traditional rites, technology, are invariably accompanied by linguistic mutations, especially in the domain of lexicon. In Gikuyu for instance a word like kirigu that denotes an uninitiated girl has lost currency after the custom of female initiation was disbanded. Culture is dynamic and so is language (Iraki 2004).

\section{The genesis of ethnic rivalry in Kenya}

\subsection{Pre-colonial Kenya}

Kenya has a mosaic of 42 ethnic communities that settled in their ancestral homes around the 1500s (Wanguhu 2006) to replace and subjugate the Khoikhoi. The latter were hunter-gatherers. Indeed, the Bantus - the biggest group demographically - is believed to have descended from a place called Meroe in current Ethiopia; the Second group, the Nilotes (Kalenjin, luo, Maasai, etc) rolled down the river Nile from Southern Sudan and spread to Uganda and Kenya. The Cushites (Boran, Somali, Rendille, etc) came from Somali and occupy the North-Eastern fringes of Kenya. Far from idyllic, the rapport between these diverse communities (cultures) oscillated between blissful peace (intermarriages, barter trade, adoptions across cultures, common grazing, etc) and deadly hatred characterized by savage killings, plunder, mercenaries, etc. (Wanguhu 2006).

The scenario changed little with the arrival of the British in 1895. True, the skirmishes were reduced to a minimum thanks to the Maxim gun but the new conquerors deployed divide and rule tactics and preyed on deep cultural prejudices to consolidate their political stranglehold in Kenya (Kenyatta 1938, Gatheru 2005, Elkins 2006, Anderson 2006). A case in point was the Maasai who were hired as mercenaries (against recalcitrant Kamba, Gikuyu and Nandi) and protectors of the British imperialists (Gatheru 2005, Wanguhu 2006).

The period beginning in 1920, when Kenya became an official British colony, and 1963 can rightfully be named the period of struggle against colonialism and cultural imperialism. Thomas (2003) details the cultural war between the Gikuyu people and the British missionaries with respect to female circumcision in the 1920s. The missionaries were in umbrage against the practice and even more outraged by polygamy. These two practices were central to the Gikuyu people; circumcision prefaced adulthood and opened the gate to matrimony whereas polygamy was an auspicious sign of opulence since time immemorial.

To add insult to injury, the settlers lobbied the British government to occupy the choicest pieces of land, especially in the Central highlands of Kenya and in the Rift valley. This meant that indigenous people were displaced from the ancestral land and forced to live as squatters in the new white farms.

Land is sacred to ancient peoples as it is the source of sustenance and enjoyment of life. Mother land incarnates the spirituality of a people as it hosts the spirits of the ancestors and points to the 
future. Swearing by the land is second only to swearing by God the creator of the universe (Gatheru 2005).

The culturally dislocated and economically deprived Kenyans were now utterly subjugated by colonialists until the onset of the Mau Mau liberation war in the 1950s (Gatheru 2005). The war was very costly to Kenyans in terms of human loss but symbolically momentous in terms of ruffling the feathers of colonialists (Elkins 2006, Anderson 2006). Freedom was no longer an option but an incontrovertible reality. Kenya became independent in 1963 and the Union Jack, vestige of British colonialism, was lowered forever.

\subsection{Independent Kenya}

Kenya gained independence in 1963 with a clear development agenda of eliminating ignorance, disease and poverty. However, the political intrigues of Jomo Kenyatta and Jaramogi Oginga Odinga $^{2}$, agents of the West (read Capitalism) and East (read Communism) respectively, seriously undermined the development of Kenya. With Kenyatta gaining the upper hand, Kenya, despite some remarkable GDP growth by 1973, became characterized by dictatorship, personality cult and political patronage, especially in favour of the Gikuyu ethnic community.

Kenyatta's ideological feud with Odinga turned ethnic as the entire Luo community was demonized and marginalized politically and economically. Odinga had come to epitomize the entire luo ethnic community. The brutal assassination of Tom Mboya ${ }^{3}$ in 1969 by a Gikuyu assassin ignited the ethnic hatred between the Gikuyu people and the Luo people.

Kenyatta's administration marginalized the other ethnic communities as he bestrode the country like the Colossus of Rhodes. Between 1963 and 1978 (when he died), the chance of building a cohesive nation was completely lost. What was left was a country marked by ethnic tension with every community wishing that their own will occupy the high office and shower them with goodies. Kenyatta had not addressed the age-old wounds and prejudices that the British had condoned and fuelled.

The seeds of ethnic strife were slowly pushing the ground from beneath like the strike in Zola's Germinal.

In sharp contrast, Julius Nyerere, President of Tanzania, may have had less success economically but he had managed to forge a sense of nationhood among the panoply of Tanzania's ethnic groups. The strongest glue was the Kiswahili language that continues, inter alia, to define Tanzanian identity. In Kenya, the language plays second fiddle to English and cannot claim the "majesty" of the colonial tongue. In fact, in most instances, English is considered the language of the elite, the polished, and the sophisticated (Ireri-Mbaabu 1996).

\footnotetext{
${ }^{2}$ Kenyatta and Odinga were from the Gikuyu and Luo ethnic communities respectively. The two groups had forged a formidable political group against the other communities.

${ }^{3}$ He belonged to the Suba ethnic group who have been acculturated by the Luo.
} 
Between 1978 and 2002, Daniel Arap Moi ruled Kenya like his predecessor. In fact his "philosophy" was called Nyayo philosophy which literally translates into Philosophy of footsteps. But Moi was not as lucky as his predecessor. After 1973 and following the sharp rise in world oil prices, most economies of the developing world were on a tail-spin. The 1980s saw the introduction of the Structural Adjustment Programmes (SAPs) that almost put the last nail into the coffin of African states (Boukary 2003). In terms of development, the country was in rack and ruin. But Moi's autocratic rule did not help things. Like his predecessor and the British, he played the ethnic card adroitly to maintain his grip on the land. It is believed that his ethnic community (the Tugen group) reaped immense benefits from Moi's presidency. For instance, key government positions and business deals were reserved for the select Tugen who were the president's side-kicks. In the meantime, development remained elusive to most of the Kenyans. Poverty, disease and ignorance were festering.

The seeds of ethnic strife had already broken the ground.

\subsection{The end of the Cold War and multiparty politics}

The consequences of the collapse of the Berlin Wall in 1989 marked a new phase in Kenya's development. The lone global cop (US) had no stomach for single-party states and therefore coerced them to adopt political pluralism or face the music. After much pressure from within and without, Moi constitutionally returned the country to the political pluralism of independence. Anyone could now form a political party. There was mushrooming of parties but ethnicity quickly became an issue: parties were becoming ethnic outfits - Kenneth Matiba (a Gikuyu) fell out with Jaramogi Odinga (Luo) within the FORD ${ }^{4}$ party. In some cases, there were rifts within the same ethnic community, e.g. Mwai Kibaki creating the Democratic Party (DP) to challenge Kenneth Matiba's FORD - ASILI party.

The seeds of ethnic strife had now sprouted.

The General Election of 1992 was marked by ethnic violence, rape and displacement of people from areas where they were no longer wanted by their neighbours. "Cultural otherness" was reduced to "political otherness" and therefore viewed as a threat. Moi "won" the election and it was business as usual. The perpetrators of the heinous crimes went scot-free.

The General Election of 1997 was no different. The consequences and reactions from the political leadership were similar to those of 1992. Moi "won" again. The perpetrators of violence, rape, hate speech and murder continued to enjoy the impunity accorded them by the regime.

\footnotetext{
${ }^{4}$ FORD - Forum for the Restoration of Democracy - was split into FORD-ASILI (Matiba) and FORD-Kenya (Oginga)
} 


\section{The Kibaki presidency}

In the subsequent General Election in 2002, it was believed that a revolution was underway in Kenya. The revolution was going to sweep away the old political, economic and social order and spread out a new one its stead. Kenyans wanted development and an end to ethnic bigotry. Tribalism, corruption and political patronage were going to be put on their heads. Kenyans were in an expectant mood. Moi handed the baton of power to Mwai Kibaki, his one-time VicePresident. Kibaki had come to power on a coalition ticket - the NAtional Rainbow Coalition (NARC) - comprising people from all ethnic communities. The promise for change was formidable. The messiah had arrived (Iraki 2006).

Kibaki's first term was economically promising. Indeed, he reversed the near-negative growth of the economy to about 7\%. A remarkable feat indeed. However, his performance in the political sphere was rather dull. He seemed to follow the same path of ethnicity as his predecessors. Most Kenyans were disappointed that he could not deal with corruption. In fact, he appeared to abet economic crimes committed by members of his ethnic community, and particularly the Meru ethnic group ${ }^{5}$. Kibaki's grip of national politics slipped when he lost the national referendum on the New Constitution. Most of his detractors were from the other ethnic communities led by Raila Odinga (Luo).

Kenyans anticipated a problematic General Election come 2007. They were right since all the other General Elections after 1992 were violent. But they underestimated its magnitude. The old wounds were festering and some Kenyans wanted change quickly. Unemployment had skyrocketed, the cost of living was unbearable and the economic inequalities across and within ethnic communities had become pronounced.

\subsection{The 2007 General Election}

The Kenyan Constitution requires that for a president to win s/he requires among other things to garner at least $25 \%$ of votes in 5 of the 8 provinces in Kenya. This requirement forestalls the possibility of installing a president who has majority support from a few provinces. This means that a candidate needs to woo the votes of many Kenyans who do not come from their ethnic communities. Since this is very difficult for any one candidate, there is need to forge alliances to create winning coalitions. This has been the scenario since 2002 .

However, the coalitions do not represent a common understanding of issues but invariably it is an alliance to oust the opponents. It is an agreement between politicians on how to share the spoils. It is not uncommon to have two opposing groups at one time who then split and rearrange themselves the next moment. Now friends become foes, and now foes become friends. In

\footnotetext{
${ }^{5}$ The Gikuyu feel that Kibaki favours the Meru community to their detriment as they are accused of reaping benefits from Kibaki and yet the reality is that he benefits the Meru more. Paradox?
} 
this Hobbesian' scenario, the ordinary people suffer as the political elites wine and dine at their expense. This is the illusion of ethnicity and goodies.

The prevailing fallacy defends the idea that political, economic and social injustices in a community can only be resolved by having a president from its ethnic background. It seems Kenyatta, Moi and Kibaki give credence to this fallacy. But what are the injustices we are alluding to? (Iraki 2008).

\section{What ails Kenya's development?}

\subsection{Historical injustices}

Kenya is mainly agricultural and the agricultural sector employs about $60 \%$ of the population. This means that land is a sacred commodity. The colonial government under constant pressure from the white settlers hived off huge chunks of land from the African people and gave it gratis or for a song to the whites. This was the case in parts of central Kenya and in the Rift Valley where indigenous people were displaced and forced to work as squatters in white farms. Monetary tax was imposed on them to force them to proved cheap labour. Others like the Maasai were tricked into moving away from their fertile grazing grounds to the less lucrative Laikipia plains (Wanguhu 2006).

The colonial dispensation was one of disruption and dislocation of a cultural life that some Kenyans held dear. The Mau Mau uprising sought to rid the country of the colonial yoke and to return to the idyllic bliss of pre-colonial days.

Many Kenyans looked forward to independence as the day when the injustices would be addressed. The Maasai and the Gikuyu wanted their lands back and/or compensation. The Mau $\mathrm{Mau}^{6}$ wanted a slice of the independence cake since they, rightly or wrongly, believed that they and not anyone else had driven the British out of Kenya. But this was not to be. The political elites found that the demands were onerous and unrealistic.

\subsection{Political injustices}

As discussed above, the nascent spirit of nationalism in 1962-3 was dampened by the rift between Kenyatta and Oginga as the two were at the antipodes of the Cold War. Kenya was a multi-party state but Kenyatta had little room for other parties. By 1966, he was quick to ban any political party that threatened his power. He was not only a Gikuyu chief but also the unchallenged leader of Kenya. Consciously or unconsciously, he embraced the culture of greed for land and ethnic bigotry that saw almost all the important political appointments go to his Gikuyu people.

\footnotetext{
${ }^{6}$ A group of freedom fighters mainly composed of the Gikuyu ethnic community.
} 
Moi and Kibaki do not escape the same analysis. Even with the advent of political pluralism the Kenyan people still feel that the current political set-up cannot render them justice. There is a constant feeling among Kenyans that they deserve better political leaders. But the message is: Elect the coalition that will benefit your ethnic group.

\subsection{Economic injustices}

It is a truism that most young Kenyans are jobless. This disempowering situation creates anxiety and despondency among the youth. The cost of living has always been seen as unbearable by people who are either jobless or earn peanuts. The slums of Nairobi are forever expanding negating the quality of life for very many Kenyans. To these vulnerable groups, a new political dispensation promises hope and sunshine that never materialize. These groups are a tinder- box and small spark can produce real great havoc.

Alongside extreme indigence is extreme and obscene opulence displayed by Kenyans, mainly from the beneficiaries of drug-trafficking, corruption and clientelism. As this apex of the economic pyramid wallow in extreme wealth, the majority of the people in the country have been going through a very rough patch.

\subsection{Social injustices}

Related to economic injustices are social injustices epitomized by insensitivity to providing the needy with essential services such as water, electricity, healthcare systems, recreational facilities and security. In most parts of the country, these services are either absent or inadequate. In contrast, the leafy neighbourhoods are well-lit with manicured golf courses and ample security from the Kenya police. Crime is high in the poorer neighbourhoods but this can attributed in part to poor policing by the Kenyan security forces.

\subsection{Lack of a common culture}

Is there a common set of values that could pass for a Kenyan culture? For instance, is Kiswahili a shared language among Kenyans? Most researchers have found that in most parts of Kenya, only the local indigenous languages can be said to be shared ${ }^{7}$ Kiswahili remains a language for people who have been to a formal institution or who have had contact with people from the cities or towns. Ironically, Kiswahili becomes a national language that is not national.

Studies of the history of the French language (Walter 1988) show that, even in Europe, nationalism was not easy to achieve. For instance, before the First World War, France was replete with Roman and Celtic dialects but by the end of the Wars, the Frank dialect from the north was imposed and generalized in the entire country. The move sounded he death knell for the dialects, which today are not as vibrant as before. The net result is that French nationality was consolidated around the French language.

\footnotetext{
${ }^{7}$ Discussion with Myles Osborne (Harvard University) after conducting research among the Kamba in 2005.
} 
But other studies show that nationalism in modern Europe was defined, forged and consolidated through warfare. It was the wars between the empire builders that marked the boundaries and identities of European countries. However, in Africa, the boundaries of States were decided upon by European powers in the Berlin Conference of 1885. Broadly, they are artificial and often times controversial. For East Africa, ethnic communities were divided into two, one in Kenya, the other in Uganda (the case of Samia and Luo) or in Tanzania (the case of the Maasai).

\subsection{Cultural stereotypes}

Cultural stereotypes can be farcical but they can also have grave consequences in the psyche of a country. Although in the main they are hyperbolic and meant to elicit humour, in some instances the constant replay of these stereotypes might wire them strongly in our psyche. A few examples will suffice here.

Gikuyus (20\% of population $)^{8}$ are reputed to be industrious money-lovers like the Jews. To confirm that one is dead, you have to drop a coin on the ground. If he's faking it, he will surely grab the coin! They are also deadly thieves and conmen.

The Luyhia (16\%) are known to love eating chicken and ugali and making love. It is said that when they rob a house the first thing they do is light up the fire to make ugali ${ }^{9}$ and chicken.

The Luo (14\%) have a knack of living luxurious lives that are beyond their means. After a nasty road accident, a Luo was informed that he had lost his hand. He then exclaimed: "And what happened to my Rolex watch?". The Luos are also said to be very educated compared to other Kenyans. They take great pride in speaking the Queen's English.

The Kalenjin (12\%) are said to be the best runners since they grow up running in the highlands, while the Maasai are known to be fearless and fierce. They are said to be less sophisticated intellectually compared to the luos and the rest.

The Kambas are the witches and sorcerers par excellence while the coastal peoples are lazy and laid-back. They wait for a coconut to fall and hit them on the head for them to eat it!

The Somalis and Borans are just too garrulous and cantankerous. It is believed they always carry weapons of one form or other.

Indians are believed to be business magicians who rely on their polytheism to become prosperous, while white Caucasians are educated, kind and wealthy. In this logic, Indians are deprecated while whites are much appreciated without analysis.

\footnotetext{
${ }^{8}$ Kenya has about 30 million people according to the population census of 1999 . Unconfirmed figures place the population at 40 million in 2009.

${ }^{9} \mathrm{~A}$ meal made of maize flour cooked in water. It is a staple food among many communities in Kenya.
} 
In sum, while there might be a grain of truth that helps build a stereotype, much of it is mainly exaggeration that borders on ethnic bigotry. There is no analysis but generalization in the stereotype. This is the stuff that can erode efforts to build a national culture if it is taken at face value.

\subsection{Insular mentality}

It is argued that when a civilization becomes inward-looking, its days are numbered. This was the case for ancient giants like Babylon, Egypt, Greece, Rome, etc. Kenyans tend to believe they are better than anyone else in Africa and therefore they have nothing to learn. This insular mentality weakens their ability to cope with experiences where their neighbours have done very well. For instance, ethnic bigotry, Kenya's stock-in-trade, is very minimal in mainland Tanzania. Why can't Kenya learn from her good neighbour?

In conclusion to this section, we can say that Kenya's problems are very clear. This may explain why since the advent of political pluralism, the injustices have found expression in untold violence and destruction of property during and after General Elections.

Nevertheless, it is rather simplistic to reduce the violence issue to a question of ethnicity, although ethnic bigotry plays a role. In the next section, we review the two reports from the commissions created by the Kenya Government, namely the Kriegler and Waki reports, in a bid to further explore the Post-Election violence in Kenya and its impact on development.

\section{Reports on the election violence}

\subsection{Kriegler Report}

The monster of ethnic suspicion and hatred reared its head shortly after Kibaki was declared the winner of the Presidential poll by the Electoral Commission of Kenya (ECK). The announcement and subsequent hurried swearing-in ceremony was all but credible.

Both spontaneously and in a coordinated manner youth groups and militia maimed and killed innocent people as a way of protesting the outcome of the poll. In total about 1,200 Kenyans were killed. Properties including homes, cars and businesses were torched by the angry and disenchanted youth who were financed by wealthy politicians and businessmen. The country had plunged into chaos and despondency.

Fortunately, the country was stopped from going over the precipice by Kofi Annan, the former secretary-General of the United Nations. He managed to secure a peace deal by end January between Kibaki's PNU (Party of National Unity) and Raila's ODM (Orange Democratic Movement). The result was the Grand Coalition that is now Kenya's ruling organ.

In the peace accord, it was recommended that two commissions be created with a view to examining the violence and also examining the December 2007 elections to determine the causes 
of the violence (Kriegler 2008). Later, the two were constituted, the first chaired by Justice Kriegler from South Africa, and the second, the Independent Review commission (IREC), chaired by Justice Philip Waki of Kenya.

\subsubsection{Findings of the Kriegler report on violence}

Kriegler attributed most of the blame on the Constitutional fuzziness that created an ECK that is virtually toothless, dependent, ill-equipped and unfit to mid-wife a truly independent, reliable and democratic election. The ECK in its current status and functions cannot guarantee Kenyans that it is impartial and reliable. It is seen as an extension of the Executive. Kriegler recommended a total overhaul to create a new ECK or an entirely new body that will be more committed to impartiality, efficiency and professionalism.

Further, Kriegler notes that "there was generalized abuse of polling, characterized by widespread bribery, vote-buying, intimidation and ballot-stuffing. To this end, Krieger warns "all political role-players in Kenya should recognize that materially defective elections accompanied violence will remain a feature of life in their country absent (sic) a concerted and sustained commitment to electoral integrity by all Kenyans."

\subsubsection{Critique of the Kriegler report}

In our view, the report captures the institutional weaknesses that contributed to the catastrophe after the poll results. However, it is our submission that institutions are creations of a culture. It is a people's ensemble of desirables (values) that push them to establish institutions to protect and foster the values. In the case of Kenya, the Constitution borrowed from India by the colonialists has not changed significantly to integrate what may be desirable to Kenyans. Since independence, the presidents have continued to enjoy the imperial powers of the Governor. This abuse of power is precisely the root cause of all constitutional hitches including the creation of a servile and spineless ECK to ensure the president and his cronies get re-elected.

The Constitutional Review process became too politicised by the warring leaders, notably Raila and Kibaki. Drafts of the proposed new Constitution were challenged to the extent that when the Attorney-General produced the draft document it was rejected by the Referendum of November 2005. Raila had a field day espousing the weaknesses of the document but mainly focusing on the unwieldy powers of the presidency.

Now, the Grand Coalition has promised a new Constitution by next year but the political class is not so keen. Clearly, it is the politicians who drive Kenya's agenda, and not the people. With the current 50-50 sharing of cabinet positions between ODM and PNU, and with Raila's appointment to the premiership, there is little hurry to talk about a new constitutional dispensation. The ordinary person is left wondering whether the whole noise about a new constitution was just a political gimmick. 
In conclusion to the Kriegler report, it can be noted that culture subtends institutional development. In a context of distrust, it is important to have institutionalized checks and balances to ensure equity and promote democracy. To this end, it is important to promote common cultural values that will subsequently inform the creation of new institutions. Without this cultural transformation, a new ECK or a brand new constitution will be devoid of meaning. Let us now turn to the Waki Report.

\subsection{Waki report}

The Waki report, whose mandate was to examine the December 2007 from various dimensions, notes in the Executive Summary that "In some ways the post-election violence resembled the ethnic clashes of the 1990s and was but an episode in a trend of institutionalization of violence in Kenya over the years." He further notes that "...the post-election violence was more than a mere juxtaposition of citizens-to-citizens opportunistic assaults. These were systematic attacks on Kenyans based on their ethnicity and their political leanings."

The report further observed that the security apparatus in Kenya was lax and ill-prepared to deal with the magnitude of the ethnic conflagration. It therefore recommended "...concrete measures to improve performance and accountability of state security agencies...). More critically, it recommended the creation of a tribunal to prosecute those mentioned in the other secret report ${ }^{10}$ to curb the culture of impunity in Kenya.

The two reports have divided the political class into two: those in favour of implementation and those against. Kibaki is already talking of forgiveness even when the suspects have not yet been tried. The Attorney General is screaming that the Waki report does not provide adequate evidence to prosecute the suspects. This reaction could step from the fact that the Kibaki administration has been adversely mentioned in the report.

Within ODM, things are not alright either. A section of the party has been opposed to the implementation of the report but Raila and most of his colleagues from Nyanza are for the implementation. ODM's future as a formidable political party is hanging in the balance. But should these reactions surprise us?

\subsubsection{Critique of the Waki report}

In fine, the Waki report, just like the Kriegler report, is a good document that seeks to redress ethnic-related violence that seriously undermines Kenya's development agenda. Strengthening the security apparatus is an excellent thing but we should not forget that police officers are not spared the ethnic biases that affect ordinary people. In fact, they may be more predisposed to ethnic bigotry than the people they are meant to protect. Indeed, some officers were involved in looting and maiming during the post-election violence as evidenced by television cameras.

\footnotetext{
${ }^{10}$ Waki handed a separate envelope to Kofi Annan containing names of people who should be prosecuted by the tribunal or The Hague.
} 
The prosecution is a good thing too. However, in a country polarized by ethnicity, the prosecution should be expertly and professionally done to eschew accusations of witch-hunting and tribalism. But the ultimate solution would be a cultural transformation via education and socialization that would have no room for criminals, whether they are within or without the ethnic confines. Without the cultural transformation that accords Kenyans new values and norms, development, whether political or economic will remain a pipe-dream.

\section{Recommendations on using culture to promote development}

The violence witnessed every time Kenya holds a General Election cannot just be reduced to ethnicity. Rather, it is the expression of deep frustrations that ordinary people have been experiencing for a very long time. It is evident that ethnic violence becomes the easiest though deadliest outlet for frustrations that are not essentially ethnic. To begin to redress the impasse, we recommend a few institutional and cultural changes. But change is a process, not an event. It takes time before change can be accepted and internalized by people.

\subsection{Political changes}

Change the Constitution to ensure that it reflects the culture and aspirations of the people of Kenya. In this domain, the political class should not be left alone to determine the content and spirit of the document. This should be an all-inclusive process. A constitution that caters for the few rich people or a certain community can undermine democracy and seriously jeopardize development. The idea of a rotational presidency à la Suisse could ensure that every large community has a chance to the presidency. Other domains to be ironed out include the electoral institutions and processes, timetable for elections, recall of non-performing elected officers (President and members of parliament), just to mention a few.

An annual published audit of all public offices to ensure that gender and ethnic representation is reasonable. The move would forestall the tendency of those in power appointing people from one gender or one ethnic community. The government should publish the results of the audit in the media for all to read.

Strengthen key institutions that provide security to the ordinary people.

Enhance public trust and confidence for the government by implementing the recommendations of the various costly commissions that the government has been creating, e.g. Commissions on land, devil-worship, etc.

\subsection{Economic changes}

Stimulate economic recovery through innovation, investment in young people to create jobs, exploration of new industries (service as opposed to products). Innovation can open new economic opportunities for all. Also, provide for proportional distribution of resources to all constituencies via the existing Constituency Development fund. Institute external financial audit 
for the CDF committees annually to rein in fraud. Such a move will minimize the idea that only certain communities are benefiting from government of the day.

Address the land issue with urgency, determination and wisdom to heal the rift between certain communities, especially in the Rift Valley. The government can also invite ideas from the concerned communities on the way forward (compensation, re-allocation, etc).

Commensurate salaries and taxation for all public officers including members of parliament and judges. This would eliminate the super class of Kenyans and create a sense of equity. If all ordinary people who toil in the sun are not tax exempt why should the MPs and judges be? ${ }^{11}$

\subsection{Cultural changes}

Work toward creating a common set of core values that define the vision of the country and invest in the institutionalization of those core values through the educational system. These could include honesty, diligence, honour, hard-work, thrift, entrepreneurship, innovation, autonomy, concern for others, etc. It is not desirable that some communities should promote business and become rich while others watch and become poorer and poorer. This is lack of a common vision to become a prosperous nation. Wanton consumerism without regard for tomorrow is a practice that should be reconsidered.

Culture is dynamic and this fact should be reflected in the evolution of Kenya's values. Time, experience and new knowledge demand that we change our way of thinking. This may call for a revision of values. For instance, if male circumcision has been proven to reduce HIV/AIDS prevalence it may be advisable to change and adopt it (Menya, 2008). In addition, it makes no sense to continue a practice that is potentially harmful to some members of our society. There is little value in clinging to a cultural practice that is in contradiction with our general welfare. In addition, it is atrocious for cultural warriors to argue for practices that jeopardize our existence. For example, wife inheritance may have a sound rationale behind it in our society (protection of the widow, support for children, protection of estate of the diseased, etc) but in the times of HIV/AIDS prevalence, prudence must be applied. A new whole family may be exposed to the virus. Culture is not an object to be preserved in a glass casing. It evolves with our thinking and our aspirations.

Collective social responsibility should woven into the fabric of society, especially with regard to children and those with severe handicaps. Parental care should not be optional but mandatory and actionable. The entire society should be held responsible for ensuring that parents perform their duties accordingly. This would reduce the number of street children and abandoned families. Programs for feeding the hungry, e.g. hot soup kitchens in the US could be introduced

\footnotetext{
${ }^{11}$ Parliament has just rejected a bill intended to enable the taxation of allowances of Kenya's members of parliament. There are 210 members who earn a taxable Kshs 200,000 and a tax-exempt Kshs 600,000 making them one of the highest paid MP's in the world. Conversion rate: $1 U S \$=75 \mathrm{Ksh}$.
} 
to cater for the people in great need. This would be real inclusion where everyone feels that they belong.

Promote the use of ordinary rather than pedantic Kiswahili as a way of creating a common medium for expression for all that will purvey our collective values. The current Kiswahili taught in schools appears harder than English or French, and yet it is our language; many people would rather try English which is a foreign language.

\section{Conclusions}

At best culture and development have a dialogic relationship; they have a mutual effect on each other. A people's thinking that hatches new projects to realize their dreams and aspirations is the best example of culture leading to concrete development. These projects could be legal frameworks, institutions, products or processes that move the society from one level to the next.

In the case of Kenya's history, fundamental injustices, including the people's desires and aspirations have been swept under the carpet with the hope that they will resolve themselves. The consequence as we have outline above is sporadic violence between ethnic communities as they try to get a glimpse of justice. Whether the violence is spontaneous of planned is immaterial; what matters is that there are deep-rooted issues that need be addressed, failure to which development will continue to eschew the country. The reversal of economic growth from $7 \%$ to about $2 \%$ shows how the ethnic rivalry can affect development within a very short time.

The Kriegler and Waki reports are important documents as they address institutional weaknesses that Kenya can redress in the hope of creating a just society. But institutions with a weak cultural base have a short shelf-life; they cannot withstand the test of time. That is why it is important to begin to promote a core of values shared across the country as a new culture that Kenya would like to embrace.

Education plays a very important role in ensuring that we are socialized through the values desired by the society. The same could be some in Kenya where the core values (desirables) become integrated into the school curriculum and reflexes of the people.

A national language like Kiswahili should be more utilized in articulating Kenya's development issues. However, its form need be handled with care so as not to alienate the language from the people it is meant to serve (Shitemi 2008, Ireri Mbaabu 1996, Okoth-Okombo 2001).

Since change is not an event but a process, the recommendations above will take time to take root but the results would be very beneficial. In conclusion, we submit that culture is not a spice to be added to food of development, rather it is part and parcel of the main ingredients. It is not an optional but integrated factor. There is need to integrate the three levels of change: political, economic and cultural to bring about meaningful and durable change in Kenya.

\section{References}


Anderson, D. (2006) Histories of the hanged: Britain's dirty war in Kenya. New York: W.W. Norton \& Company.

Boukary Adji (2003) L’Afrique à la croisée des chemins : problématique du développement. Abidjan : Editions Eburnie.

Elkins, C. (2006) Britain's Gulag: The brutal end of an empire in Kenya. New York: Henry Holt \& Company.

Gatheru, M. (2005) Kenya:From colonization to independence, 1888-1970. USA: McFarland \& Company Inc.

Iraki, F.K. (2006) Political survival and the economy. In Daily Nation of 5 January 2008.

Iraki, F.K. (2004) Language and culture: a perspective. In Wajibu, April issue.

Iraki, F.K. (2008) Kenya's healing hampered by old, open wounds. In Sunday Nation of 27 January 2008.

Ireri-Mbaabu (1996) Language Policy in East Africa, Nairobi: General Printers.

Jomo Kenyatta (1938/1965) Facing Mount Kenya. New York: Random House Inc.

Ojaide, T. (2007) Ordering the African Imagination: Essays on culture and literature. Lagos: Malthouse Press Ltd.

Okoth-Okombo, (2001) Language Policy: The forgotten parameter in African Development and Governance strategies.Inaugural lecture, Nairobi: University of Nairobi Press.

Pinker, S. (1994) The language Instinct. London: Penguin Press.

Shitemi, B. (2008) Kiswahili as a tool to unite Africa. In Sunday Nation of 23 November 2008.

Tchegho, J-M. (2003) La décentralisation, l'éducation, l'unité nationale et la lutte contre la pauvreté au Cameroun. Yaoundé : Editions Démos.

Thomas, L.M. (2003) Politics of the womb:Women, reproduction and the State of Kenya. California: California University Press.

Menya, W. (2008) My intention is to save lives, says woman behind male cut. In Sunday Nation of October 26, 2008.

Wanguhu, N. (2006) Kenya's Ethnic Communities: Foundations of a nation. Nairobi: Gatundu Publishers Ltd.. 
The Journal of Language, Technology \& Entrepreneurship in Africa, Vol. 2. No.1. 2010, ISSN 1998-1279

\section{Documents consulted}

Independent Review Commission (IREC) or Kriegler report

Commission for Investigation of Post Election Violence (CIPEV) or Waki report

Source: http//www.communication.go.ke 